\title{
Del Cerrado a la Altillanura: peligros y retos
}

\author{
Daniel Omaña (Q.E.P.D)
}

El problema es preciso y concreto. Esta ECOPETROL y su subsidiaria ENERGY en capacidad de garantizar que sus 12.000 hectáreas de caña sembrada en la Altillanura, para la producción de biocombustibles, no serán dentro de 50 años una tierra invisible, degrada o desertificada. Tenemos serias dudas. Pero, si es así sería lo primero que deberían decir para promocionar su proyecto. ¿Qué sería una producción sostenible para la humanidad? Hay algunos ejemplos históricos. La producción del valle del Nilo en Egipto desde 4.000 años y de algunas regiones de China que producen arroz hace otro tantos milenios. Agotar el recurso suelo, no renovable, en 50 o 100 años es depredación, desde el punto de vista de la evolución de la humanidad. Lo que ha sido, es y seguirá siendo fuente de hambrunas, pandemias y guerras de rapiña por los recursos restantes. Una buena ilustración es la alarmante avalancha de capitales para la compra de tierras, de parte de los fondos soberanos y las multinacionales, en Asia, África y América Latina, y su consecuente fenómeno de acaparamiento. (Ver: www.fao.org y www.grain.org ). La altillanura es simplemente parte del fenómeno.

Supongamos, solo en aras de discusión, que nuestras dudas son validas y que efectivamente la tierra cultivada por ENERGY será inservible dentro de unas cuantas décadas. Grave, porque significa que si se incorpora la Altillanura o la Orinoquia a la gran producción agroindustrial (soya, maíz, etc.) con las tecnologías convencionales, en unas cuantas décadas tendríamos toda una región degradada y/o desertificada. Esta es la voz de de alerta. Es lo que está sucediendo en el "Cerrado Brasilero".

"De continuar la agresión indiscriminada al cerrado estaremos incorporando otro desierto a las 1.370 hectáreas por hora que se producen en el mundo" dice Luis Pinheiro, quien fuera presidente de la Empresa Brasilera para la Investigación Agropecuaria, EMBRAPA, tan nombrada hoy. ¿Cuál agresión indiscriminada? La que se hace con la tecnología convencional: Labranzas, insumos químicos, monocultivos, eliminación de la biodiversidad, etc. La curva del contenido de la materia orgánica del suelo en el cerrado es tendencialmente decadente. Es decir, degradante. Esto, todo el mundo lo sabe pero lo que sucede es que aun sigue siendo un negocio relativamente rentable y un medio para obtener recursos estatales.

¿Existe una tecnología consolidada para incorporar la Altillanura a la gran agro producción sin riesgo de degradación del suelo? Categóricamente, no. Hace falta investigación no solo en Colombia sino también en Brasil. El gran reto tecnológico y de investigación es justamente evitar lo que está sucediendo en Brasil. "...quiero recordar a la Universidad y a las Unidades de Investigación, que el cerrado está esperando una investigación profunda que se oriente para la vida en plenitud, y no para la destrucción que llevara a la muerte no solamente de ese preciso bioma, sino también del extraordinario manantial hídrico que tiene el cerrado en su hogar" (Pinheiro). 
¿Se han dado los primeros pasos en tal sentido?. Categóricamente, si. Destacable la labor de CORPOICA, que seguramente con las uñas, ha investigado, experimentado y desarrollado técnicas bajo la orientación acertada de construir, "hacer", suelo y no de destruir, depredar. Son unos patriotas, por no decir quijotes, porque esto no ha estado en el centro de las preocupaciones ni de la sociedad ni del estado, lo cual tiene consecuencias presupuestales también "degradantes". Es sin lugar a dudas el punto y base de partida, junto a la contribución de otras entidades universitarias y de investigación que seguramente apuntaran en la misma dirección. El aprovechamiento de la experiencia brasilera nos puede llevar a consolidar un paquete tecnológico que permita la incorporación sostenible de los suelos de la Orinoquia a la producción mundial agropecuaria.

De otra parte, es importante tomar en consideración que el fosforo, que es básico en la tecnología convencional actual, es otro recurso que se agota en el planeta. Se estima que para el año 2.050 estaremos abocados a un desabastecimiento crítico. Otra razón más para reiterar que la sostenibilidad de la seguridad alimentaria dependerá de la fertilidad de los suelos, su biodiversidad y salvación de recursos hídricos. De esa "vegetación fantasmagórica" de que habla despectivamente el articulista de SEMANA y no del "brachiaria decumbes, que ayuda a mejorar el suelo" según los articulistas de EI Tiempo. Obviamente, no entendieron lo que les trataron de explicar los técnicos. (7-XI-2010).

También es válido reconocer que en lugar de subsidiar la producción de agrocombustibles, sería más útil para el mejoramiento del conjunto de los suelos de la Orinoquia y de su productividad una política de estado hacia la eliminación del uso de fuego y utilizar a cambio el recorte o desbrozamiento mecánico de pasturas y melazas, impulsado mediante incentivos, subsidios. Esta simple medida si, ciertamente, apuntaría a una verdadera revolución verde. Si a esto le sumamos la persuasión y demostración (mediante investigación, experimentación y desarrollo) a los campesinos y productores de las bondades del "barbecho", el descanso de la tierras, la rotación de potreros en ganadería y de cultivos en agricultura, las consecuencias de la labranza y utilización de agroquímicos, las implicaciones del monocultivo, la utilidad de defender la biodiversidad y los recursos hídricos, las ventajas de la integración y alternancia de la producción pecuaria y agrícola, las virtudes de los sistemas silvopastoriles y la agroforesteria, los beneficios de cuidar e incentivar la vida del suelo (microbios, hongos, bacterias, escarabajos, lombrices, etc.), la posibilidad de utilizar abonos biológicos, de bajo costo, con inoculación de cepas eficientes en la descomposición del material vegetal y en la fijación de nitrógeno, el requisito de contar con una planeación u ordenamiento de la producción acorde con las características, cualidades y vocación de cada uno de los diferentes y variados nichos ecológicos de la región, etc., etc., etc.; podríamos pensar que es totalmente factible avanzar hasta consolidar un paquete tecnológico global para la producción intensiva pecuaria y agrícola, sostenible y hasta de fertilidad tendencialmente creciente, en el conjunto de la Orinoquia. Estos son los peligros y los retos para la Orinoquia Colombiana.

(Villavicencio, octubre 8 de 2.010) 